\title{
Vozes Griôs no Ensino de Química: Uma Proposta de Diálogo Intercultural
}

\section{Griots Voices in Chemistry Teaching: An Intercultural Dialogue Approach}

\author{
Marciano Alves do Santos \\ Brasil \\ Marysson Jonas Rodrigues Camargo \\ Brasil \\ Anna M. Canavarro Benite \\ Brasil
}

Este artigo se configura como uma pesquisa participante, portanto, uma pesquisa pensada para transformação social na qual pesquisador e comunidade intervém juntos em uma demanda da própria comunidade. Cabe salientar que um dos pesquisadores é quilombola. Assim, objetivou-se discutir a seguinte questão: como saberes e fazeres tradicionais de matriz africana dialogam com o ensino de química? Para responder essa questão desenvolvemos um trabalho em comunidades quilombolas (kalungas) do Estado de Goiás, primeiro, ouvindo e aprendendo sobre conhecimentos tradicionais mobilizados pelos Griôs, bem como sobre suas demandas e, em seguida, planejando intervenções pedagógicas intentando estabelecer um diálogo entre esses saberes e a ciência escolar (química). Nossos resultados mostraram ser possível concatenar saberes tradicionais e o conhecimento químico, possibilitando a valorização da ciência de matriz africana culminando na proposição de uma sequência didática e reflexões acerca da mesma que podem orientar a prática docente, especialmente no âmbito da Educação Escolar Quilombola.

Palavras-chaves: ensino de química; quilombo; saberes tradicionais.

As a participant research study, we design this work for social transformation, in a way that the researcher and the community intervene together in a demand from the community itself. It should be noted that one of the researchers is a Quilombola man. Thus, our objective was to discuss the following question: how can traditional knowledge and practices of African origin and chemistry teaching dialogue? To answer this question, we developed an investigative work in Quilombola communities in the state of Goiás (the kalungas). First, we listen and learn about traditional knowledge mobilized by the Griots, as well as about their demands, and then we plan pedagogical interventions to establish a dialogue between this knowledge and school science (chemistry). Our results showed that it is possible to connect traditional knowledge and chemical knowledge, enabling the valorization of African science, and culminating in the proposition of a 
didactic sequence with reflections about it that can guide the teaching practice, especially in the context of the Quilombola School Education.

Keywords: teaching chemistry; quilombo; traditional knowledge.

\section{Introdução}

Os povos e comunidades tradicionais no Brasil são constituídos por, aproximadamente, cinco milhões de brasileiros e brasileiras e ocupam $1 / 4$ do território nacional, segundo o Programa das Nações Unidas para o Desenvolvimento (PNUD). São grupos sociais espalhados em todo território nacional, cada qual com as suas especificidades: "quilombolas, ciganos, matriz africana, seringueiros, castanheiros, quebradeiras de coco de babaçu, comunidades de fundo de pasto, faxinalenses, pescadores artesanais, marisqueiras, ribeirinhos, varjeiros, caiçaras, praieiros, sertanejos, jangadeiros, ciganos, açorianos, campeiros, varzanteiros, pantaneiros, caatingueiros, entre outros" (Paraná, 2019, p. sp.).

À vista disso, povos e comunidades tradicionais podem ser caracterizados como segmentos diversos culturalmente que assim se reconhecem e que, também, possuem formas específicas de estruturação social, ocupando e utilizando territórios e recursos naturais como requisito para sua perpetuação seja cultural, social, religiosa etc., por intermédio de práticas sociais ensinadas de geração a geração (SEPPIR, 2013).

Nesta comunicação, estamos interessados/as nos povos e comunidades tradicionais de matriz africana - os quilombolas - que podem ser compreendidos como a parcela da população brasileira que se organiza com base em valores civilizatórios e a partir da visão de mundo africanos, oriundos do processo diaspórico e em resistência ao escravismo criminoso nos tempos do colonialismo histórico, o que propiciou uma continuidade civilizatória no Brasil, "constituindo territórios próprios caracterizados pela vivência comunitária, pelo acolhimento e pela prestação de serviços à comunidade" (SEPPIR, 2013, p. 12).

Nessas estruturas sociais uma figura imprescindívelé o/a griô, palavra abrasileirada do termo Griot que é de origem franco-africana, do império de Mali, e que faz referência aos contadores de história, aos que ensinam a tradição em sua comunidade (Pacheco, 2006). As palavras que saem da boca de um griô são uma "ponte entre os tempos", pois não apenas representam um elo entre o passado e a atualidade, mas também repercutem sobre o futuro daqueles/as que as ouvem sendo, por isso, um referencial para a vida (Silva, 2013, sp). De acordo com Pacheco (2006), o/a Griô é:

Todo (a) cidadão (ã) que se reconheça e seja reconhecido pela sua própria comunidade como herdeiro (a) dos saberes e fazeres da tradição oral e que, através do poder da palavra, da oralidade, da corporeidade e da vivência, dialoga, aprende, ensina e torna-se a memória viva e afetiva da tradição oral, transmitindo saberes e fazeres de geração em geração, garantindo a ancestralidade e identidade do seu povo (p. 63). 
Os/As griôs são fontes de conhecimentos tradicionais que, por sua vez, tem sido alvo de debates nos últimos anos em várias áreas do conhecimento: antropologia (Cunha, 2012), direito (Maciel, 2012), biologia (Paiva, 2014), química (Regiani, 2014) entre outras, mas destacamos o interesse das ciências da natureza por essa ciência tradicional. Segundo Cunha (2010), conhecimentos tradicionais são sistemas, assim, no plural, pois são ancorados em epistemologias diversas. Talvez, o quanto forem variados tais povos e comunidades, tão diversas sejam suas formas de recortar a realidade e sistematizá-la, de forma que alguns saberes podem ter validade e sentido apenas em âmbito local (Cunha, 2007). Para Bastos (2013):

As diferentes populações humanas apresentam um arsenal de conhecimentos sobre o ambiente que as cerca. Propriedades terapêuticas e medicinais de animais e plantas, a percepção dos fenômenos naturais, como as estações do ano, tempo para plantar e colher, classificação de animais e plantas, organização de calendários, dicionários, sazonalidade de animais e sua relação com aspectos da natureza são organizações que formam um cabedal de saberes que comumente são chamados de conhecimentos tradicionais (p. 6195).

Contudo, importa dizer que alguns autores/as diferenciam as expressões conhecimento tradicional e saber tradicional, enquanto outros/as as utilizam de forma indistinta. Segundo Perrelli (2008), é preciso reconhecer a polissemia dessas expressões e tomar as devidas precauções quanto aos seus usos. Assim, neste excerto, utilizaremos conhecimento e saber como sinônimos e, ainda, entendendo que a adjetivação tradicional não diz respeito a algo antigo, atrasado e estático, mas a um corpo de conhecimentos dinâmico e em construção. E

...que a riqueza e a força do "tradicional" residem, justamente, na sua constante capacidade de renovação, produção e reprodução, isto é, na sua possibilidade de desaparecimento, de descoberta e redescoberta, e não na pretensa pureza/autenticidade decorrente da ficção da imutabilidade (Perreli, 2008, p. 385).

Todavia, não nos interessa discutir aspectos filosóficos e semânticos dos usos desses termos. Intentamos discutir os conhecimentos tradicionais como conteúdos curriculares, para o currículo em ação do ensino de química, notadamente, na Educação Escolar Quilombola. E, nesta comunicação, entendemos por currículo em ação, o currículo ativo, aquele que é materializado em sala de aula e não apenas os documentos oficiais que podem orientá-lo. Neste sentido, currículo é compreendido por nós como as experiências escolares que abrangem todas as interações e tudo que possa influir no processo educacional do/a aluno/a como indivíduo (Menegolla \& Sant’Anna, 2003).

$\mathrm{Na}$ esteira do pesquisador Silva (2012), compreendemos o currículo como prática social que nos constrói como sujeitos idiossincrásicos. Não é, por isso, apenas uma operação cognitiva de transmissão de conhecimentos e, muito menos, a tentativa de se fazer emergir uma essência humana antecedente à linguagem, ao discurso e à cultura. Pelo contrário, entendemos por currículo o discurso que, ao representar versões particulares sobre a pessoa e a sociedade, compõe-na como sujeito. O currículo é o que 
nos constitui e nos posiciona como indivíduos e alocados multiplamente "no interior das diversas divisões sociais" (Silva, 2012, p. 190). Neste sentido, o currículo também traduz relações de poder e estas se inscrevem nele através do processo de seleção dos conteúdos.

O currículo brasileiro, neste sentido, não tem comportado as especificidades dos povos e comunidades tradicionais, uma vez que "a cultura que temos hoje por herança funda-se da divisão de dois domínios de saberes, de um lado, as ciências, de outro, os saberes da tradição" (Almeida, 2010, p. 58). A hegemonia do conhecimento científico e o diálogo hierarquizante que tem sido estabelecido com o conhecimento tradicional são os principais entraves. Por sua vez, o conhecimento tradicional e o conhecimento científico possuem maneiras diferentes de dialogar com o mundo, assim como, de regimes de pensamento que desvelam e sistematizam a realidade. No entanto, da pretensa superioridade surgem ideias equivocadas, nas quais a ciência seria um empreendimento neutro, livre de ideologias e a-histórico. Os conhecimentos tradicionais, por sua vez, seriam "entendidos como cristalizados, sem evolução, populares, tratados como filhos bastardos da aventura do conhecimento e excluídos do âmbito da socialização e comunicações oficiais" (Almeida, 2010, p. 61).

Nas correntes epistemológicas cientificistas, à guisa de exemplo, considerar-se-ia que as maneiras de interpretar, classificar os fenômenos pelos donos dos conhecimentos tradicionais seriam descartadas pela ciência, pois apenas o método científico poderia ser válido e, por ser um conhecimento não dotado de juízos de valor, a ciência moderna seria expressão da verdade absoluta ou, pelo menos, a melhor disponível no momento. Defendemos, nesta investigação, porém, que a ciência é um empreendimento social e histórico e, consequentemente, uma construção humana, logo, não é neutra, é intersubjetiva e é edificada por inúmeros métodos e metodologias adequadas a objetivos específicos.

De acordo com Pantoja (2014), uma das diferenças entre a ciência moderna e a tradicional é que a primeira tem a pretensão de universalidade enquanto a segunda objetiva a validade local convivendo, sem maiores problemas, com outros saberes. Porém, importa reconhecer que essas formas de saber possuem semelhanças. De acordo com Cunha (2007) citada em Pantoja (2014):

$\mathrm{Na}$ ciência trata-se dos pressupostos científicos, aquilo do qual se parte para erigir todo o resto. No caso dos saberes locais pode-se falar em pressupostos culturais, embora os científicos sejam igualmente históricos e culturalmente situados. É impossível compreender certas afirmações da biologia darwinista, por exemplo, se não se está minimamente familiarizado com certos pressupostos desta linha de pensamento, como a ideia de seleção natural. Da mesma maneira, é impossível compreender as afirmações dos seringueiros do Alto Juruá sobre formigas que viram cipós, ou madeiras que viram pedra, se não se está informado que para esses grupos a metaformose entre espécies é um pressuposto de sua ciência naturalista (p. 6).

Fato é que esses conhecimentos são diferentes, pois se constroem a partir de 
regimes de pensamento diversos, o que não deveria implicar em classificações que tenham como meta hierarquizá-los, ou mesmo suprimir o tradicional do currículo escolar. Logo, as instituições escolares devem valorizar o conhecimento dos mais velhos que não tem sua origem na academia, mas que podem ser incluídos nas experiências escolares. De acordo com Silva (2005), porém, o modelo de currículo eurocêntrico despreza os saberes não hegemônicos, e acaba por funcionar como um mecanismo de exclusão. Enquanto as crianças e jovens pertencentes ao grupo dominante são, em sua maioria, bem-sucedidos na escola e veem seu capital cultural sendo fortalecido, as crianças e jovens de outros segmentos, geralmente, engrossam estatísticas de fracasso escolar, pois, dentre outros elementos que impulsionam esse insucesso, conteúdos da cultura desses grupos não são selecionados no currículo oficial, ou quando são figuram como saberes populares, sem complexidade e folclóricos (Silva, 2005).

Importa dizer que esse filtro que conforma nossos currículos é racista e eurocêntrico, fruto do processo histórico de colonização e colonialidade/modernidade que garantiu - e ainda garante - seu triunfo. Segundo Quijano (2010), a colonialidade e a modernidade são fenômenos interdependentes e, inevitavelmente, imbricados. Dizem respeito ao processo de desenvolvimento europeu a partir do subdesenvolvimento das colônias de exploração, portanto, traduzem não apenas a pilhagem de recursos naturais desses lugares e o consequente enriquecimento da Europa escravizando africanos/as e aniquilando autóctones, mas, também, aos mecanismos de dominação e opressão colonialidade do poder, do saber e do ser - que transcenderam o colonialismo histórico.

É neste cenário que o racismo se consolidou como forma de alocar pessoas na estrutura social a partir da categoria raça que, por sua vez, como constructo social abrange não apenas um conjunto de sinais diacríticos de um segmento social (cor da pele, forma do nariz, cabelo, boca etc), mas, ademais, a cultura desses grupos, portanto, seus conhecimentos, seus valores civilizatórios, tradições, usos e costumes (Gomes, 2012). Em sua dimensão epistêmica, o racismo atua suprimindo epistemologias nãobrancas seja na academia, seja na escola - nas produções científicas e na socialização da cultura.

Neste sentido, especificamente em relação ao ensino de ciências e suas tecnologias, os/as professores/as precisam tomar certo cuidado em fazer comparações entre a história africana e europeia, pois, caso contrário, torna-se comum considerar apenas a Europa como fonte do saber e a África e sua diáspora como fonte da ignorância (Cunha Jr., 2010). Em vez disso:

O ensino de ciências deve abordar informações sobre a origem do conhecimento ocidental e sobre a história de conhecimento produzido no continente africano. Para tanto, deve questionar a visão dominante que coloca a Europa, e mais especificamente a Grécia, como única fonte inicial do pensamento científico. Dessa forma, indica-se a importância de questionar o eurocentrismo das ciências naturais e o papel que assumiu na história em reforçar e legitimar explorações de africanos e seus descendentes (Silva, 2009, p. 151). 
Questionar o eurocentrismo das ciências da natureza e engendrar ações que objetivem superar o racismo epistêmico e a colonialidade nesse campo do saber podem ser alocados no projeto de decolonialidade. De acordo com Bernardino-Costa (2018), o projeto decolonial - ou também chamado de giro decolonial - refere-se aos esquemas epistêmicos e políticos de luta e suplantação da colonialidade do poder, do saber e do ser por um lado e, por outro, ao concomitante estabelecimento de um diálogo novo entre os sujeitos que vivenciam o lado mais nefasto da modernidade eurocêntrica. Trata-se de uma mobilização organizada protagonizada por grupos que resistem e reexistem para terminar a descolonização incompleta nas Américas no século 18, e na África e Ásia no século passado.

Implementar uma educação antirracista no ensino de ciências/química, portanto, que se preocupe em atender e respeitar características culturais dos povos e comunidades tradicionais de matriz africana, "valorizando e trazendo esses saberes e conhecimentos para o interior dos muros da escola, implica num forte desafio que é a reflexão acerca de um currículo escolar" (Haerter et al., 2013, p. 274). Entretanto, são ainda poucas as pesquisas que versam sobre o ensino de química e sua possibilidade de diálogo com a ciência tradicional, principalmente, na modalidade de Educação Escolar Quilombola.

Dentre essas, podemos citar Franzão (2017) que realizou um trabalho em seis escolas que oferecem o ensino médio no território Kalunga e uma no Jardim Cascata. A autora concluiu que existe a necessidade de um ensino de química que dialogue com a realidade de cada comunidade quilombola e aponta para a falta de cursos de licenciatura quilombola, a construção de um projeto político pedagógico unitário para cada escola e a falta de cursos de capacitação para os docentes que atuam nessas escolas. Apesar de a Educação Escolar Quilombola ser uma modalidade de educação, o currículo que se verifica nela é o da Educação Básica regular, e esse modelo de currículo tem selecionado conteúdos hegemônicos e possui um código cultural próprio e não correspondente às representações culturais reivindicadas nesses espaços.

Advogamos que a inter-relação entre o saber escolar com o saber tradicional, em uma perspectiva intercultural, pode representar uma alternativa para o ensino de química efetivando princípios da Educação Escolar Quilombola: valorizar a cultura de cada comunidade, afirmar e garantir a manutenção de sua diversidade étnica (Brasil, 2013). Interculturalidade, neste artigo, é compreendida conforme Santos (2008) para o qual diz respeito ao contato entre diferentes conhecimentos de forma recíproca e intervalorizada para o ganho de experiência, portanto, sem haver hierarquizações que denotem uma pretensa superioridade da ciência branca/europeia. Não se trata de uma abordagem rasa ou de usar o saber tradicional como objeto da ciência moderna, mas de garantir a presença de saberes não hegemônicos no currículo em ação e de insurgência ao epistemicídio - supressão, aniquilação e subalternização de saberes não ocidentais. Assim, defendemos que a escola quilombola não deveria ser apenas uma instituição alocada nos limites geográficos de uma comunidade quilombola, mas servindo, também, como ponte entre os atores/atrizes sociais que a constituem e a produção cultural: os/as 
alunos/as, os/as professores/as, as ciências e os conhecimentos tradicionais.

A partir desses pressupostos, objetivamos, nesta comunicação, promover o diálogo entre os conhecimentos tradicionais - extrativismo de óleo de coco - de duas comunidades em um território quilombola do estado do Goiás e o conhecimento químico no currículo escolar, a saber, conteúdos relacionados aos conceitos de substâncias, misturas, propriedades específicas da matéria e forças intermoleculares; propor estratégias de ensino com esse fim e discuti-las no âmbito da Educação Escolar Quilombola. Logo, consideramos que, em nossa área de pesquisa, praticamente inexistem pesquisas e materiais didáticos que deem suporte teórico-metodológico ao ensino de química nessas escolas, a partir de um diálogo intercultural entre a ciência química do currículo e os saberes tradicionais. Destarte, apresentamos nas seções que se seguem, o estudo de planejamento e design de uma intervenção pedagógica pensada para ser executada na Educação Escolar Quilombola a partir das contribuições de griôs entrevistados/as.

\section{As tessituras do percurso metodológico}

A pesquisa relatada neste artigo surgiu a partir do momento em que o aluno de pós-graduação quilombola - doravante denominado PGQ - passou a integrar em 2011 o Laboratório de Pesquisas em Educação Química e Inclusão (LPEQI) do Instituto de Química (IQ) da Universidade Federal de Goiás (UFG), e a participar das reuniões semanais do Coletivo Ciata $^{1}$ - grupo de estudos sobre descolonização do ensino de ciências/química. Durante a graduação, PGQ foi aluno no Programa Institucional de Bolsas de Iniciação Científica (PIBIC), desenvolvendo pesquisa com a seguinte temática "Cultura Africana e Ensino de Química: Estudos sobre a Formação Docente". No primeiro semestre de 2016, PGQ foi aprovado no mestrado do Programa de Pós-Graduação em Química da UFG, no Campus Samambaia, e a ideia que prevaleceu para PGQ foi a de desenvolver um trabalho investigativo na educação quilombola, isto porque, PGQ é o primeiro quilombola mestre em química da UFG, quiçá do Brasil. Assim, o ponto de partida dessa pesquisa foi dialogar com o sujeito social negro e quilombola que retorna à sua comunidade por uma demanda que não é apenas dele, mas da comunidade tradicional quilombola da qual é representante.

Essa, portanto, foi uma pesquisa participante (PP), um trabalho organizado a partir de uma demanda em que o/a pesquisador/a e a comunidade, ambos sujeitos da pesquisa, planejam, agem e avaliam juntos/as a intervenção (Demo, 2008). Neste sentido, como sugere a nomenclatura "participante", entendemos que essa técnica de investigação se caracteriza não apenas pela inserção do/a pesquisador/a na comunidade respeitando as idiossincrasias da mesma, tornando-se legitimado pelo grupo social investigado como parte do mesmo, mas, sobretudo, pela inclusão da comunidade

1 Coletivo Ciata é um grupo de estudos do LPEQI em que o nome faz referência à Hilária Batista de Alemeida, a Tia Ciata, mulher negra, mãe-de-santo em cuja casa nasceu o samba no Rio de Janeiro no século passado. Sua casa era uma "pequena África" no Brasil, local de resistência da cultura negra. 
na pesquisa, como defendeu Brandão (1987). Importa dizer, então, que PGQ é um líder quilombola e professor de química. Dessa forma, sua posição é íntegra dentro da PP como sujeito pesquisador (também membro do Coletivo Ciata) e informante, representante de seu grupo social e partícipe de todas as etapas do trabalho investigativo junto à sua comunidade. $\mathrm{O}$ desenvolvimento desse percurso foi organizado em 4 fases: 1) montagem institucional e metodológica do projeto; 2) estudo preliminar da região e da população envolvida; 3) análise crítica dos tópicos considerados prioritários pelos participantes da pesquisa; e 4) a programação e desenvolvimento de um plano de ação (Le Boterf, 1984). A Figura 1, a seguir apresentada, sumariou a estrutura do trabalho de pesquisa.

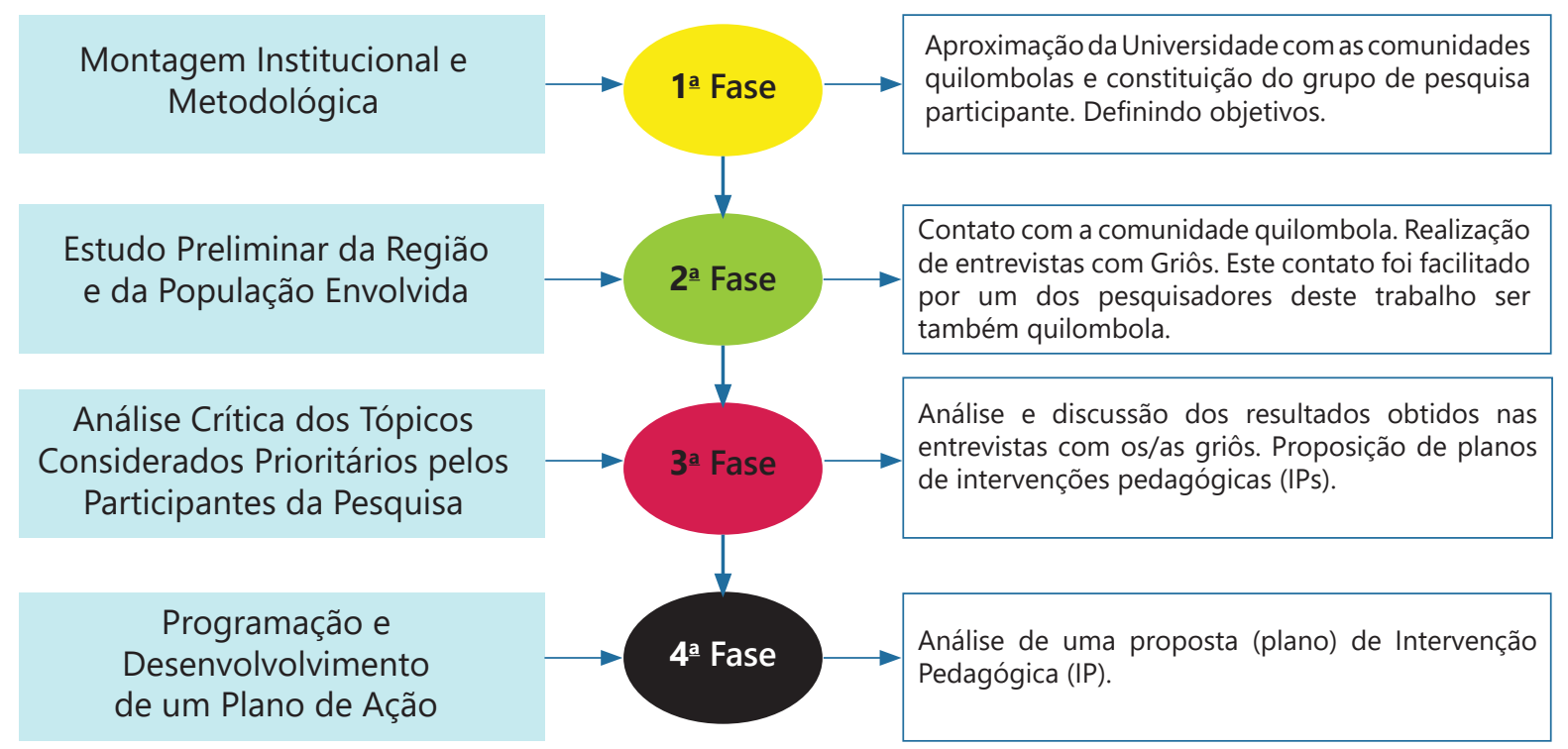

Figura 1. Resumo das etapas do percurso metodológico

Fonte: autores.

A primeira fase da pesquisa foi caracterizada pela aproximação entre a universidade e as comunidades quilombolas onde residem os sujeitos desta PP. De acordo com Le Boterf (1984), as tarefas que constituem essa etapa: a consolidação da parceria entre a comunidade e as instituições (no caso a UFG), a elaboração e socialização do projeto de investigação e seus objetivos, metodologia, referencial teórico e resultados esperados, e a distribuição democrática de funções. Desse modo, foram os sujeitos da pesquisa uma professora formadora do Laboratório (PF), o mestrando quilombola (PGQ) e os membros das comunidades quilombolas - professores/as da Educação Escolar Quilombola, extrativistas de óleo de coco e forneiros (griôs) e alguns estudantes das escolas locais.

Nesta primeira fase foram estabelecidos dois objetivos elaborados pelo grupo de PP: mapear conhecimentos tradicionais que poderiam ser incluídos na disciplina química 
da escola quilombola e planejar intervenções que operacionalizassem objetivamente o debate intercultural na sala de aula. Foi definido, também, que na etapa seguinte necessitaríamos realizar uma entrevista com os/as griôs, primeiro para conhecermos mais detalhadamente os seus saberes e, segundo, para compreender como e o quanto esses representantes do grupo social envolvido tinham interesse na manutenção de seus conhecimentos tendo a escola como um local de sua divulgação.

A segunda fase é descrita por Le Boterf (1984) como o momento de diagnóstico preliminar e provisório da pesquisa. Logo, constituiu essa etapa da investigação conhecer a geografia e história dos quilombos investigados, visitar as casas dos/as griôs para, antes da entrevista propriamente dita, estabelecer-se vínculos de confiança com os sujeitos da pesquisa e destacar o seu protagonismo na mesma. Em sequência desenvolveu-se um estudo sistematizado do que Le Boterf (1984) nomina por "descoberta do universo vivido pelos pesquisados".

Neste sentido, foram realizadas entrevistas semiestruturadas com vistas a elucidar sobre os saberes e fazeres tradicionais de cada sujeito social, nesse caso com 4 forneiros (FN1, FN2, FN3 e FN4) e com 5 famílias que detém o conhecimento de extração de óleo de coco (FA1, FA2, FA3, FA4 e FA5), todos/as na faixa etária acima dos 40 anos. Esta etapa foi realizada no período entre novembro de 2016 a junho de 2017 nos quilombos rurais de Morro de São João e Vão das Almas no território Kalunga. Neste artigo, abordamos apenas as discussões no que se refere às entrevistas com os/as extrativistas de óleo de coco e ao plano de intervenção pedagógica proposta a partir dessa interação. As análises das entrevistas com os forneiros foram publicadas em Santos, Camargo e Benite (2020, no prelo).

Os encontros com os/as griôs foram gravados em áudio para posterior transcrição e análises dos dados. De acordo com Minayo (1996), "podemos apontar três finalidades para essa etapa: estabelecer uma compreensão dos dados coletados, confirmar ou não os pressupostos da pesquisa e/ou responder às questões formuladas, e ampliar o conhecimento sobre o assunto pesquisado, articulando-o ao contexto cultural da qual faz parte" (p. 69). As respostas dos/as griôs às entrevistas foram organizadas em extratos constituídos por turnos de fala enumerados em ordem cronológica. Cada turno representa a abertura e fechamento de uma fala. A Figura 2 mostra a sequência do roteiro da entrevista semiestruturada feita para os/as quilombolas que detém o conhecimento sobre extração de óleo de coco.

Três eixos norteadores organizaram a entrevista feita com os griôs. O primeiro, "saberes e fazeres tradicionais e ancestralidade", objetivou coletar informações a respeito do processo de comunicação/divulgação do conhecimento tradicional na comunidade. Assim, neste momento, os griôs responderam sobre quando e com quem aprenderam sobre a técnica de extração de óleo de coco e como ocorre o processo de transferência desses saberes na comunidade.

O segundo eixo, denominado "Concepção sobre os métodos de separação de mistura por densidade e evaporação", teve como objetivo compreender o processo 
de produção do óleo de coco, as etapas do mesmo e os conhecimentos mobilizados. E, por fim, no terceiro eixo norteador - "Importância de preservar o conhecimento tradicional" - objetivamos coligir dados sobre o processo de comunicação do saber tradicional e formas como a escola poderia contribuir para manutenção dos mesmos a partir da visão dos/as griôs entrevistados/as.

Nessa etapa, utilizamos a gravação apenas em áudio das entrevistas, pois assim os sujeitos da investigação solicitaram. Obedecendo a princípios éticos, o Termo de Consentimento Livre e Esclarecido (TCLE) foi gravado, pois os/as Griôs, por nós entrevistados/as, não tiveram a oportunidade de se alfabetizarem e, por isso, não puderam assinar o TCLE. Por tratar-se de pesquisa com seres humanos de comunidade quilombola, esta pesquisa foi aprovada pelo Comitê de Ética da UFG sob o código 209/2012, sob coordenação da Professora Dra. Anna M. Canavarro Benite.

\begin{tabular}{|l|l|}
\hline Eixos Norteadores & Questões \\
\hline $\begin{array}{l}\text { Saberes e fazeres } \\
\text { tradicionais e } \\
\text { ancestralidade }\end{array}$ & $\begin{array}{l}\text { 1. Quando e com quem você aprendeu a fazer óleo de coco? } \\
\text { 2. Qualquer pessoa pode fazer óleo de coco? }\end{array}$ \\
\hline $\begin{array}{l}\text { Concepção sobre } \\
\text { métodos de separação de } \\
\text { misturas por densidade e } \\
\text { evaporação. }\end{array}$ & 3. Você pode descrever como é o processo de fabricação de óleo de coco? \\
\hline $\begin{array}{l}\text { Importância de preservar } \\
\text { o conhecimento } \\
\text { tradicional. }\end{array}$ & $\begin{array}{l}\text { 4. Como é a relação dos jovens com a produção de óleo de coco? Eles se } \\
\text { interessam? }\end{array}$ \\
$\begin{array}{l}\text { 5. Em sua opinião você acha que haveria algum lugar ou forma para } \\
\text { garantir que o jovem aprenda esse ofício? } \\
\text { 6. Você acha que a escola seria um lugar para garantir que esse } \\
\text { conhecimento tradicional dos antepassados não se perca? Como? }\end{array}$ \\
\hline
\end{tabular}

Figura 2. Roteiro para a entrevista com fazedores de óleo de coco

Fonte: autores.

A terceira fase da PP é definida por Le Boterf (1984) como o momento de análise crítica dos dados preliminares antecedente à ação social. Assim, como recomenda o citado autor, nessa etapa as análises são desenvolvidas com auxílio de um/a pesquisador/a orientador/a para que se possa ter um conhecimento objetivo da realidade e para que possam servir como instrumento para intervenções efetivas. No âmbito da pesquisa relatada, PGQ é quilombola e professor de química e, neste contexto, foi incluído como professor/a na escola quilombola local em que procedeu com as análises das entrevistas realizadas anteriormente. Assim, o objetivo foi que, a partir dessas análises se pudesse idealizar planos de intervenções pedagógicas.

Para essa análise a técnica utilizada foi a análise da conversação conforme referencial de Marcuschi (1986). Esse aparato metodológico de análise busca desvelar nos diálogos - em nosso caso, entrevistas - os contextos de sua produção que possa 
dar-lhes sentido e continuidade. O fio condutor de uma análise da conversação "é a descrição e a explicação das competências que os falantes comuns usam e de que se valem para participar de interações inteligíveis e socialmente organizadas" (Heritage \& Atkinson, 1984, p. 1).

Os resultados obtidos pelas entrevistas foram analisados e discutidos em um ponto de vista que considerasse as diferenças e similitudes entre as duas formas de conhecimentos: científico e tradicional. A partir dessa análise buscamos propor um diálogo com a produção de intervenções pedagógicas (IPs) que contemplassem a Lei $10.639 / 2003$ que, por sua vez, propõe uma mudança curricular em todas as modalidades da Educação Básica, a saber, incluir o ensino de cultura e história africana e afrobrasileira $^{2}$. Sob este ângulo, buscamos introduzir os conhecimentos tradicionais de comunidades de matriz africana no currículo de química na escola local, em outras palavras, sistematizamos estratégias - intervenções pedagógicas (IPs) - para efetivar o deslocamento epistêmico do currículo. Isso foi possível partindo dos dados empíricos coligidos nas entrevistas, a discussão dos mesmos com a literatura da área e com plano de curso da disciplina de química tendo como premissa contemplar conceitos científicos que são objetivos de aprendizagem nas diretrizes curriculares oficiais.

Por fim, desenvolvemos a quarta fase da PP em que, segundo Le Boterf (1984), configura-se um plano de ação e o realiza em concomitante avaliação. Este constituise de ações educativas que permitam problematizar a situação vivida, estabelecer providências a serem tomadas e ações educativas que as tornem factíveis para, também, propor soluções em curto, médio e longo prazo para as demandas coligidas. Importa dizer, porém, que, nesta comunicação, não foi possível, por motivo de espaço, apresentar e discutir todos os dados das intervenções dessa quarta fase, a saber, a discussão dos turnos de fala produzidos nas aulas propriamente ditas. Apresentamos, nesta etapa, a proposta de intervenção associada aos conhecimentos de extração de óleo de coco e as implicações decorrentes de uma possível reprodução da mesma na educação escolar quilombola. O desenvolvimento da IP não será apresentado e discutido, pois gerou uma grande quantidade de turnos de fala que não seria possível discutir neste excerto.

Portanto, nesta comunicação, a quarta fase foi caracterizada pela discussão do plano de uma das IPs elaboradas por PGQ sob orientação de PQ (Coletivo Ciata) que poderiam possibilitar o diálogo entre a química do currículo escolar e os conhecimentos tradicionais em uma perspectiva intercultural. Essa última análise pretendeu dar subsídio para atuação profissional de professores/as de química na Educação Escolar Quilombola apontando caminhos e ressalvas quanto à forma de se estabelecer o contato entre os saberes tradicionais e os científicos. Em vista disso, o plano de IP discutido foi pensado para a primeira série do ensino médio em que, geralmente, se discute conceitos como densidade, propriedades específicas da matéria, os conceitos de substâncias, misturas e forças intermoleculares.

2 A referida lei foi alterada em 2008 pela Lei 11.645 que acresceu a obrigatoriedade do ensino de cultura e história indígena. 


\section{Resultados e discussões}

Para planejar e intervir no âmbito da Educação Escolar Quilombola efetivando princípios como a afirmação e manutenção de elementos da cultura quilombola, como, por exemplo, os conhecimentos tradicionais, é preciso, antes, ouvir o que esta comunidade tem a dizer e ecoar sua voz, em especial, dos/as griôs da cultura, pessoas reconhecidamente detentoras e produtoras da tradição, que se colocam a serviço da manutenção identitária da comunidade. Neste sentido, nosso trabalho começa na aproximação de PGQ com os/as griôs, os/as extrativistas de óleo de coco, no território Kalunga em Goiás. A partir desse envolvimento de PGQ, como mediador de uma relação entre a escola e os/as griôs e seus conhecimentos tradicionais, entendemos que:

É de grande importância perceber que existem possibilidades de relacionamento entre a cultura hegemônica; no caso a escola; e a cultura popular subalterna dinamizando a cultura e dando voz a histórias e conhecimentos renegados pela história oficial. Cada vez mais, percebemos que a escola abre as portas para os conhecimentos locais, de diferentes formas, ampliando seu campo de atuação na formação de seus estudantes, possibilitando o acesso tanto aos novos conhecimentos como aos velhos (Choe, 2009, p. 19).

Dessa forma, PGQ pretendeu romper com o diálogo hierarquizante entre a ciência moderna escolarizada e os conhecimentos tradicionais inferiorizados e suprimidos do currículo, no ensino de química, por meio de um assunto comum: a extração de óleo de coco que é uma das muitas técnicas de conhecimento transferidas para o Brasil com os/as africanos/as escravizados/as. Esse conhecimento permanece vivo, principalmente, dentro dos quilombos.

De acordo com Cunha Jr. (2010), “o uso de gordura vegetal é mais um exemplo interessante da influência africana na sociedade brasileira" (p. 31). Isto posto, PGQ investigou a relação do conhecimento de extração de óleo de coco dos/as griôs e sua relação com a ancestralidade como valor civilizatório afro-brasileiro. Ao questionar "com quem o/a senhor/a aprendeu a extrair óleo de coco?", PGQ obteve as seguintes respostas:

1- FA1: Aprendi com meus bisavôs, minha avó. Vi eles mexendo, aí aprendi a fazer.

2- FA2: Aprendi com minha mãe.

3- FA3: Com minha mãe, vi minha mãe fazendo. Aí a gente vai aprendendo, né? Com as coisas.

4- FA1: Com minha mãe.

Os turnos 1, 2, 3 e 4 revelam o caráter ancestral do processo de apropriação dos conhecimentos tradicionais nas comunidades quilombolas quando os/as griôs citam os/ as bisavós, avós e mães como aqueles/as de quem aprenderam as técnicas de extração. Ancestralidade aqui se relaciona a hierarquia, não como principio básico para se exercer 
poder tal como nas sociedades colonizadoras, mas hierarquia é valor civilizatório poderoso afrodiaspórico. É na verdade uma ferramenta de ensino e aprendizagem, de respeito ao tempo das coisas, das pessoas e de ancestralização de quem veio primeiro. Quem veio primeiro é ancestralizado por quem veio depois. O exercício de poder e controle tem base no medo e não é isso que se faz nas sociedades tradicionais (Fatunmbi, 2014).

Importa dizer que essa ancestralidade não é caracterizada pelo grau de parentesco entre o/a griô com aqueles/as com quem aprendeu, em vez disso, em consonância com Oliveira (2009), compreendemos a ancestralidade como aspecto civilizatório de resistência africana que engendra o processo histórico-cultural do negro no Brasil, e produz no campo sócio-político um projeto alicerçado em princípios como a inclusão, respeito a diversidade, valorização dos saberes dos mais velhos etc. Fundamentada na experiência tradicional africana, a ancestralidade permeia todas as manifestações da cultura negra brasileira, e é atributo idiossincrásico de qualquer grupo racial que reivindique valores africanos (Oliveira, 2009).

FA1 e FA3 expressaram ainda outros aspectos do processo de apropriação do conhecimento tradicional: "Vi eles mexendo, aí aprendi a fazer", “...vi minha mãe fazendo. Aí a gente vai aprendendo, né? Com as coisas." Estes aspectos referem-se à tradição oral e à memória, sobre as quais entendemos que as comunidades negras as utilizam

...como metodologia de ensino com os seus descendentes. Seja nas contações feitas durante as rodas de conversa ou no ensino do ofício do dia a dia, os mais velhos ensinam aos mais novos as formas de ver e viver o mundo, buscando preservar seus costumes e adaptar-se às influências introduzidas pela convivência com outras culturas e pelas inovações e tecnologias do mundo contemporâneo (Almeida \& Miranda, 2015, p.1).

Neste sentido, os turnos 1 e 3, acima transcritos ratificaram que os/as griôs são guardiões da memória, imprescindíveis para construção da identidade de uma comunidade tradicional de matriz africana, pois por meio de suas narrativas orais compartilham a memória influenciando a vivência do cotidiano e, também, orientando o futuro (Almeida \& Miranda, 2015). O conhecimento das etapas de extração do óleo de coco é um típico exemplo, pois trata-se de um conhecimento que vem sendo passado de geração em geração dentro dos quilombos rurais como mostraram nossos resultados (turnos 1 a 4 ).

A manutenção de determinados conhecimentos tradicionais não é fácil, pois para a extração do óleo de coco é necessário seguir algumas etapas de extenuante execução. Tal como descrevem os/as griôs nos extratos das entrevistas a seguir:

5- FA1: Você deve pegar o coco no mato, vai para o mato pegar o coco. Perto da palha, vem [e] quebra, coloca ele para secar no sol, torra ele, soca, tira do pilão e põe para cozinhar. Depois dele já fervido um bom tempo, tira a gordura por cima com a colher.

6- FA1: É só pegar ele no mato, tirar a carne, a casca dele, coloca para secar. Soca, quebra, coloca no sol para secar; quando acabar de secar, torra, como você viu eu torrando naquele dia. 
7- FA1: E vai para o pilão, mói ele até ficar escorrendo; depois joga na panela e cozinha, ferve, vai secando até brotar a gordura.

8- FA3: É...vou lá pego o coco, tiro ele de dentro do coco e põe para secar. Põe para secar uma semana, aí vai quebrar; torra, leva no pilão, soca, aí põe para ferver. Quando ferver, é... igual vai pegando por riba [por cima], pá [para] poder botar para secar.

9- FA1: Aí o óleo sobe, a água seca. O óleo sobe e fica em cima, aí pega e coloca para secar de novo.

10- FA3: Seca toda a água.

11- PQ: Mas ele sai misturado com água?

12- FA2: Sai misturado com água, aí coloca ele no fogo para ferver para secar a água.

Os resultados revelados no discurso dos sujeitos desta investigação descrevem um processo de extração caracterizado pela separação do mesocarpo e endocarpo do grão, trituração no pilão do grão, mistura do coco triturada com a água, e a evaporação da água do óleo (turnos 5 a 12). Esta manipulação consiste em um conjunto de operações unitárias, semelhante aos processos utilizados nas indústrias de alimentos.

Em 1915, Arthur Little estabeleceu o conceito de operação unitária, segundo o qual, um processo físico/químico seria dividido em uma série de etapas que podem incluir: transferência de massa, transporte de líquidos e sólidos, destilação, filtração, cristalização, evaporação dentre outros (Isenmann, 2012). Uma das operações unitárias de maior importância na extração de óleo de coco é a moagem do coco no pilão. Esse procedimento promove "um aumento área superficial/volume do alimento, que aumenta a taxa de secagem, aquecimento e resfriamento e melhora a taxa de extração e eficiência do componente líquido" (Fellows, 2006, p. 113). Ou seja, a quantidade de óleo produzida está diretamente relacionada ao quanto o grão de coco foi triturado.

Todavia, essa é uma descrição em termos que poderíamos denominar de científicos. É, por isso, uma forma de dar sentido ao mundo natural/artificial a partir de uma rede de conceitos social e historicamente construída. Por outro lado, os conhecimentos tradicionais, de acordo com Cunha (2007), operam a partir de unidades perceptuais - sons, odores, cores, sabores e texturas - e, por essa razão, os/as griôs produzem turnos de fala, fazendo referência ao que nós, na química, convencionamos nominar de operações unitárias.

Por este prisma, entendemos que tais unidades perceptuais se revelam com o uso de termos, nos turnos 5, 6 e 8, como "quebrar o coco" que traduz a percepção de uma ação mecânica; "torrar o coco" que está relacionado a um cheiro característico e mudança de cor; "secar" que diz respeito a consequente perda de umidade a partir da evaporação; a "moagem no pilão" que se refere a uma segunda ação mecânica - maceração ou aumento da superfície de contato; o processo de cocção em que se formam duas fases - 
visíveis - que possibilitam uma primeira separação da mistura, que é finalizada com o aquecimento até a vaporização da água remanescente. Expressões como "vai secando até brotar a gordura" " "tira a gordura por cima" se referem a diferença de densidade da água e o óleo. O líquido de menor densidade é o que vai flutuar sobre o outro (Figura 3) e este pode ser separado por um processo similar à decantação.

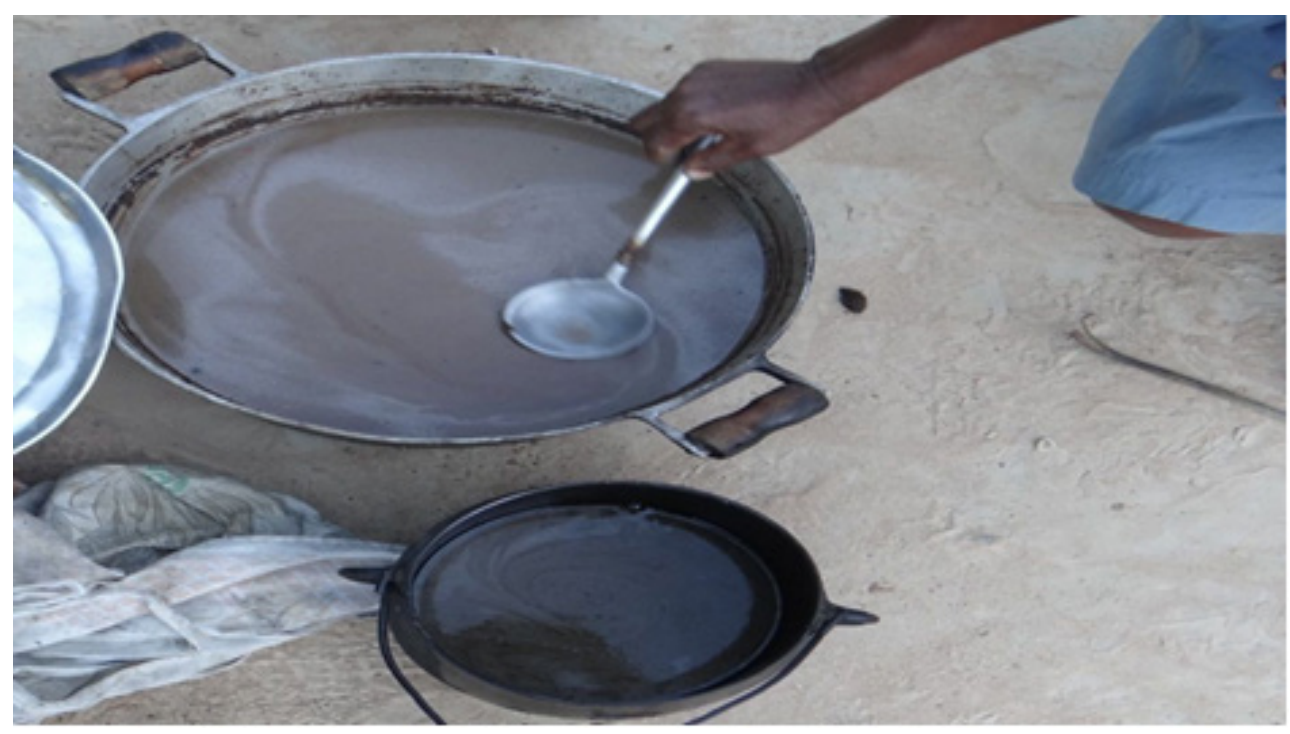

Figura 3. Separação do óleo da água

Fonte: autores.

Tais assertivas que mostram as diferenças entre o conhecimento científico e o tradicional, nos apresentam, por outro lado, um elo que os aproxima: ambos dialogam sobre a natureza e buscam dotar de sentido o mundo que nos cerca. Essa semelhança, segundo Santos (2008), alude um exemplo dado pelo filósofo Gilbert Simondon que provoca:

"qual é a diferença entre o tecnólogo, o especialista em tecnologia contemporânea, e o pajé? Nenhuma”. O pajé é aquele que faz uma viagem, estabelece um tipo de diálogo com a natureza e traz desse diálogo uma resposta para a comunidade, uma solução para um problema que a comunidade não conseguia resolver. E o que faz a tecnologia senão um diálogo humano com a natureza para tentar resolver um problema? É a mesma coisa, em patamares diferentes, de maneiras diferentes (p. 91).

Os/as griôs de nossa pesquisa, guardiões da memória quilombola, em especial da técnica de extração de óleo de coco, são representantes da ciência tradicional que, por sua vez, produz artefatos e saberes que não tem outro objetivo a não ser melhorar a vida da comunidade resolvendo problemas cotidianos. No entanto, perspectivas racistas, eurocêntricas e universalistas cunhadas na modernidade/colonialidade inferiorizam os conhecimentos tradicionais e seus/suas criadores/as atribuindo, equivocadamente, somente ao conhecimento científico o atributo da racionalidade.

Defendemos que tais concepções culminam na supressão dos saberes tradicionais 
da escola, uma vez que à ciência moderna é dado o status de conhecimento superior. Porém, cada indivíduo deveria, na sua formação formal ou não, dentro de uma cultura, ter acesso a diferentes saberes provenientes de matrizes que representam os segmentos que constituem essa sociedade. Concordamos com Nunes (2014) que:

Através do conhecimento científico, tais saberes poderiam transcender os limites que o conhecimento prático lhes impõe; buscar a compreensão matemática, física, química, biológica e geográfica para compreender os resultados obtidos nas diversas engenharias quilombolas seria um exercício enriquecedor de aprender vencendo as fronteiras cognitivas que a sua realidade apresenta (p. 94).

Destarte, é necessário romper com o silenciamento dos saberes tradicionais nas escolas quilombolas, possibilitando espaços para um diálogo. Nos turnos 13 a 19 questionamos aos griôs quem são as pessoas que produzem o óleo de coco, como é a relação dos jovens com a produção de óleo de coco e se eles se interessam em aprender as técnicas. Os/as entrevistados/as responderam:

13- FA1: Não é[são] todas pessoas que faz[em] não, mas tem muitas que faz[em]. Tem muita[as] que fazem e outros já não fazem, porque não tem interesse de fazer né.

14- FA1: Não. Não interessa, não. Porque já está acabando, né?

15- PQ: A tradição?

16- FA2: A tradição já está acabando, já.

17- FA2: Mas não é[são] muito[s] que hoje não quer[em] saber disso né, só quer[em] saber é de andar com celular na mão para cima e para baixo, né? E aí não tem jeito, né?

Muitos desses/as griôs estão morrendo dentro das comunidades quilombolas e os jovens pouco tem se interessado em aprender os saberes e fazeres tradicionais, como relatam FA1 e FA2 nos turnos 13 e 17. Durante essa pesquisa, percebemos a dificuldade em encontrar forneiros, como também produtores de óleo de coco e, os poucos que encontramos, estavam na faixa etária acima de 40 anos. Na fala da FA2 (turno 17) foi possível reconhecer um choque entre gerações, "a nossa sociedade passa por momentos de transformações. Estas mudanças ocorrem devido às novas tecnologias de informação e comunicação, que aos poucos, vão se interligando a atividade educativa" (Oliveira, Moura \& Sousa, 2015, p. 76).

Os/As jovens quilombolas no Morro de São João e Vão das Almas a cada dia têm mais acesso a celulares e a internet. FA2 denuncia que a "tradição está acabando" e que os/as mais jovens, que se ocupam mais no uso dessas tecnologias, já não tem interesse em aprender os saberes tradicionais que, na visão deles/as, tendem a desaparecer (turno 16).

Mas poderíamos nos indagar: até que ponto este entrave na reprodução e perpetuação dos saberes tradicionais caracterizariam uma dinâmica de transformação 
própria de cada comunidade ou que, em outra visão, seria evidência da colonialidade em operação? Não temos dados suficientes para dar uma resposta cabal para essa questão, mas entendemos que a manutenção de uma cultura perpassa pela escola na efetivação de um currículo interligado às demandas da comunidade em que é materializado.

Muitas vezes a falta de interesses dos jovens quilombolas pelos conhecimentos tradicionais e por outros aspectos culturais está relacionada com que é ensinado na escola. Falta conhecer a história do/a negro/a, os conhecimentos tradicionais, a importância do/a negro/a para a construção do Brasil. A supressão ou mesmo uma discussão rasa desses aspectos fazem com que o/a aluno/a tenha dificuldades de identificar-se com a própria cultura, pois parte do que é ensinado na escola os desvalorizam. De acordo com Moura (2005):

$\mathrm{Na}$ verdade, na escola é negado ao estudante o conhecimento de uma história que efetivamente incorporasse a contribuição dos diferentes estoques étnicos à formação de nossa identidade, com o agravante de que a história parcial ali apresentada como exclusiva é aquela dos vencedores, dos colonizadores ou, para precisar a afirmativa, história celebratória das classes econômica e politicamente mais bem-sucedidas (p. 78).

Segundo Cunha Jr. (2010), "esta indução errônea tem motivos e consequências, e elas despolitizam a população negra, tornam as identidades negras fragilizadas e permitem a realização de uma ampla desqualificação social das populações negras" (p. 10). A desinformação do desenvolvimento do continente africano, a mente racista dos colonizadores europeus, fez com que caracterizassem o/a negro/a sempre como mão de obra bruta, força muscular, nunca como cabeças pensantes (Cunha Jr., 2010).

Concordamos com Balieiro (2012) que as identidades — individual ou coletiva - estão sempre relacionadas com os processos de significação - entendidos como produção de significados através da cultura e das práticas sociais - e que a construção desses significados é permeada por conflitos. Portanto, a forma como imaginamos a nós e aos outros é diretamente proporcional à maneira como organizamos os significados que concorrem socialmente. E essa organização será determinada pelo contato que teremos com os discursos. Logo, em consonância com Balieiro (2012), entendemos que:

A produção de significados não é neutra e objetiva. Os discursos ao mesmo tempo em que se vinculam a amplos processos sociais, moldam a forma como as relações sociais se efetivam. Observamos como elas podem ser o veículo de subalternização social das diferenças étnico-raciais, de gênero e sexualidade. Por outro lado, podem ser o meio de questionar essas subalternizações. E onde a escola entra nessa discussão? A escola lida com discursos o tempo todo. A produção de discursos é um aspecto central na formação de estudantes. Em cada disciplina, certos conteúdos são selecionados e ensinados, alguns valores são passados e abrem a visão dos estudantes sobre como interpretar o mundo (p. 41).

Desse modo, compreendemos que nossos discursos, em sala de aula, devem promover o questionamento de subalternizações étnico-raciais. É preciso lembrar que o sucesso da economia brasileira na época da escravidão só foi possível com 
a transferência de conhecimentos, técnicas e tecnologias da mão de obra africana escravizada. A imigração forçada de africanos trouxe grande quantidade de profissionais e conhecimentos de várias áreas: agricultura, mineração, farmacologia, pesca, tecnologias têxteis, construções, sabão de cinzas, extração de óleo de coco, náutica, arquitetura, metalurgia e vários outros (Cunha Jr., 2010). Ou seja, ainda que sob o jugo de um escravismo criminoso, nossos ancestrais foram imprescindíveis para todos os ciclos econômicos do processo histórico brasileiro. Garantir que essas representações positivas do segmento negro estejam no currículo em ação, portanto, nos humaniza e nos dá protagonismo na história desestabilizando o racismo e a colonialidade que nos inferiorizam e desqualificam.

Quando perguntamos para os/as griôs se consideravam que haveria algum lugar ou forma para garantir que os/as jovens aprendessem sobre a extração de óleo de coco, as respostas foram as seguintes:

13- FA1: Estudar sobre os cocos, as etapas da produção de gorduras.

14- FA2: Os mais velhos na escola para ensinar os mais novos.

Nos turnos 13 e 14, os/as griôs reconhecem o papel da escola como local propício para reprodução cultural, pois "os mais velhos na escola para ensinar" constitui-se como espaço de ampliação do currículo escolar mobilizando na sala de aula não apenas um conjunto específico de epistemologias e conhecimentos, mas instaura a pluralidade de saberes e o reconhecimento da uma perspectiva intercultural de respeito a diversidade. Desse modo concordamos com Nunes (2014) que "a escola quilombola não pode ser apenas uma referência geográfica em um território negro; ela necessita tornar-se um espaço convidativo que redimensione os usos dos saberes tradicionais" (p. 94).

Assim, advogamos que, no caso, a química, enquanto prática social, está presente na comunidade quilombola, seja na extração do óleo de coco, sejam em outras técnicas no que tange a transformação da matéria para o bem comum em todo percurso histórico da comunidade, portanto, pode ser um instrumento para valorização dos conhecimentos tradicionais, de competência do ensino de química, na sala de aula. Passamos a apresentar e discutir como esses saberes tradicionais foram incorporados pelo Coletivo Ciata na proposição de uma intervenção pedagógica.

\section{O currículo pré-ativo: propondo uma estratégia de ação}

A partir das entrevistas sobre a extração de óleo de coco com os/as griôs, planejamos e desenvolvemos uma IP objetivando articular os saberes tradicionais e os conceitos químicos. Deste modo planejamos o design da IP 1 "Extração do óleo de coco: sobre densidade, substância e mistura" que transcrevemos no quadro da Figura 4. A intervenção foi planejada para a primeira série do ensino médio abrangendo o conhecimento tradicional dos extrativistas quilombolas, propriedades específicas da matéria, substância, misturas e forças intermoleculares. 


\begin{tabular}{|c|c|}
\hline Intervenção Pedagógica 1 & $\begin{array}{l}\text { Extração do óleo de coco: sobre densidade, substância e mistura } \\
\text { e forças intermoleculares }\end{array}$ \\
\hline Tempo & 2 aulas de 50 minutos \\
\hline \multirow{4}{*}{ Desenvolvimento } & $\begin{array}{l}\text { A aula foi programada para constituir-se em quatro momentos } \\
\text { pedagógicos. O primeiro momento refere-se à problematização } \\
\text { de algumas situações, como: por que a água e o óleo não se } \\
\text { misturam? Que tipo de mistura formam? E por que? }\end{array}$ \\
\hline & $\begin{array}{l}\text { Estas questões permitirão introduzir uma discussão a respeito dos } \\
\text { conceitos de substância e mistura e das interações moleculares } \\
\text { em substâncias polares e apolares, assim como, atender aos } \\
\text { conteúdos do currículo escolar no que tange alguns dos assuntos } \\
\text { do conhecimento químico no primeiro ano do ensino médio. }\end{array}$ \\
\hline & $\begin{array}{l}\text { Em um segundo momento, a partir dos conhecimentos } \\
\text { tradicionais de extração de óleo de coco, discutiremos com os/ } \\
\text { as alunos/as sobre as etapas do processo, na tentativa de valorizar } \\
\text { esses saberes e apontar suas semelhanças e distanciamentos com a } \\
\text { ciência moderna, e tomando uma postura crítica contra qualquer } \\
\text { forma de desvalorização da ciência tradicional. Com base nessa } \\
\text { problematização discutimos outros conceitos químicos: as forças } \\
\text { intermoleculares e o conceito de densidade. }\end{array}$ \\
\hline & $\begin{array}{l}\text { Por fim, em um quarto momento, os/as alunos/as realizarão uma } \\
\text { atividade prática sobre densidade em que o processo de avaliação } \\
\text { de aprendizagem poderá ser realizado. }\end{array}$ \\
\hline Objetivos & $\begin{array}{l}\text { Compreender a diferença entre substância e mistura; discutir } \\
\text { os conceitos de forças intermoleculares; valorizar os saberes } \\
\text { tradicionais de extração de óleo de coco; discutir a colonização } \\
\text { como fator de subalternização dos saberes tradicionais e das } \\
\text { comunidades quilombolas; discorrer sobre o conceito de } \\
\text { densidade; e relacionar estrutura e propriedade da matéria. }\end{array}$ \\
\hline Estratégia de avaliação & $\begin{array}{l}\text { Processual e contínua. Inclusão de questões referentes aos saberes } \\
\text { tradicionais na avaliação bimestral. }\end{array}$ \\
\hline
\end{tabular}

Figura 4. Plano de intervenção pedagógica

Fonte: autores

O plano apresentado constitui-se como currículo pré-ativo, ou seja, não se trata da experiência propriamente dita, mas a materialização do planejamento da mesma. Assim, em concordância com Lopes (2007), defendemos que não é possível afirmar que o currículo ativo é expressão fidedigna do currículo pré-ativo, pois este último pode até mesmo ser subvertido pelo primeiro. Todavia, entendemos que o plano é mecanismo de organização do trabalho docente definindo e operacionalizando toda a ação escolar e, portanto, relaciona conteúdos, atividades, experiências e avaliações que possibilitem o alcance de objetivos bem definidos (Menegolla \& Sant’Anna, 2005).

Importa dizer, preliminarmente, que o plano de intervenção descrito foi concebido 
a partir do referencial de educação problematizadora (Freire, 2005). Logo, concebemos a educação como ato político em que a realidade do/a aluno/a é o meio pela qual e na qual se realiza. É preciso considerar que para uma efetiva reprodução da IP sugerida é preciso superar a educação bancária - conteudista, calcada na transmissão acrítica de conhecimentos e que se supõe neutra - tão criticada por Paulo Freire. Defendemos que seja superada a dicotomia professor/aluno tornando ambos/as sujeitos do processo de ensino e aprendizagem em que, por meio do diálogo não infundido por discursos autoritários, se estabeleça uma comunicação horizontal que tenha como fio condutor a curiosidade metódica e comprometida com a apropriação do conhecimento (Freire, 2005; Francisco Júnior, 2010).

Os três momentos pedagógicos - problematização inicial, organização e generalização do conhecimento (Delizoicov, 1983) - devem, portanto, ser considerados para o desenvolvimento desta IP. No primeiro momento, as situações reais e do nível fenomenológico do conhecimento químico deverão ser exploradas. Esperamos que, nesta fase inicial, os/as alunos/as sejam desafiados a pensar e desenvolver possíveis explicações em para a formação de misturas homogêneas e heterogêneas. Esse é o momento em que as conjecturas dos/as alunos/as serão problematizadas pelo/a professor/a e os/as alunos deverão perceber que precisam de um conhecimento novo (Francisco Júnior, 2010).

No momento de organização do conhecimento serão desenvolvidos os conhecimentos necessários à compreensão das situações problematizadas inicialmente. É o momento em que os/as alunos/as serão envolvidos em percurso de busca rigorosa pelo conhecimento mediante o diálogo horizontal com o/a professor/a. De acordo com Francisco Júnior (2010), é a concretização desse diálogo entre o/a professor/a (que também é aprendiz) e conhecimento velho/conhecimento novo só ocorre se o/a docente considerar-se compreendendo a experiência e os conhecimentos prévios dos/as alunos/ as sobre essa realidade.

Salientamos que não se pode cair na armadilha de pensar conhecimentos velhos seriam os saberes tradicionais e os novos como os científicos. Conhecimento velho, nesta perspectiva problematizadora de educação, diz respeito ao conhecimento do/a aluno/a que ainda não consegue formular uma explicação correta, seja em termos científicos, sejam termos tradicionais sobre os fenômenos em estudo. Tanto o conhecimento tradicional, quanto os científicos são objetivos de aprendizagem em nossa proposta. Sobre o processo dialógico em sala de aula e como as duas formas de conhecimentos serão postas em relação que passamos a discutir.

Na Figura 4 foi descrita, sinteticamente, a sistematização do planejamento da intervenção pedagógica proposta. Tratou-se de uma IP estruturada para 2 aulas de 50 minutose, ainda, dividida em quatro momentos pedagógicos envolvendo problematização e contextualização do conhecimento para possibilitar a discussão de conceitos químicos e de saberes tradicionais de matriz africana. A inclusão dos conhecimentos tradicionais caracterizou o que denominamos de deslocamento epistêmico, ou seja, a ampliação do currículo da escola atendendo a demanda de introdução de conteúdos de epistemes 
subalternizadas no currículo em ação, a saber, a ciência de matriz africana, que parte de uma relação ser humano/natureza integradora.

A inclusão da ciência de matriz africana no currículo decorre de compartilharmos a compreensão de que os saberes dos povos e comunidades tradicionais:

São conhecimentos seculares nascidos a partir da observação, das experiências, dos ajustes das fórmulas, da necessidade de fazer algo para tornar a vida melhor. As comunidades negras são o segmento que mais absorveu e manteve vivo o legado trazido pelos africanos. Para as comunidades, a inserção dos saberes nos currículos escolares não se trata de nenhuma benevolência, mas o justo reconhecimento pelo que representam na história da nação (Fiabani, 2015, sp).

As crianças e jovens aprendem de várias maneiras dentro das comunidades quilombolas. De acordo com Santana (2015), aprendem no "festejar, no brincar, no convívio com os mais velhos, nas expressões de religiosidade e nas relações com o meio em que vivem" (p. 6). Nas comunidades Morro de São João e Vão das Almas no território Kalunga, onde entrevistamos os/as griôs, a aprendizagem não é diferente, nas aulas de ciências e química as crianças e jovens quilombolas podem descrever as funções exercidas pelos mais velhos. Essas experiências vividas pelo/as alunos podem ser potencializadas pelo/a professor/a de química para discutir e valorizar os saberes tradicionais, principalmente, em se tratando da disciplina específica daqueles saberes que tem a transformação da matéria como objeto. É isso que propomos na IP1 ao incluirmos a discussão dos saberes tradicionais em uma aula que discorre sobre estrutura e propriedade da matéria.

De acordo com Santana (2015), é preciso valorizar os conhecimentos tradicionais para que a cultura própria de cada quilombo seja "aprendida e ressignificada por uma nova geração que tem a possibilidade de viver e conviver em um lugar marcado por uma diversidade de experiências, visões de mundo e valores ancestrais vivenciados e partilhados pelo grupo" (Santana, 2015, p. 6). E essas práticas são importantes para a preservação do quilombo, para o fortalecimento da identidade de crianças e jovens quilombolas na manutenção de sua cultura. Defendemos que a aula de química é um momento em que essas práticas podem ser incorporadas. Em consonância com Kundlatsch e Silva (2017) e Regiani e Di Deus (2013), advogamos que a articulação entre conhecimento científico e tradicional, em perspectiva intercultural aproxima ciência e tradição, preserva conhecimentos e contribui para promoção da pluralidade na escola.

Tomando como pressuposto que essa proposta pode ser executada na Educação Escolar Quilombola, o/a professor/a poderia convidar um/a griô para que o/a mesmo/a possa explicar sobre sua técnica. Essa experiência ainda pode ser possibilitada pela visita da turma à casa dos griôs em que os mesmos poderiam apresentar a produção do óleo de coco e suas etapas. O/a professor/a pode utilizar essa atividade prática como meio de valorizar esses atores sociais que, na sua maioria, já são conhecidos/as dos/as alunos/as. Neste sentido, o/a docente deve ter a premissa de que sua posição, como representante da ciência moderna (química), não é a de afirmar ou negar a validade do conhecimento 
tradicional ou mesmo daquele que traduz a ciência tradicional para ciência europeia chancelando ou não as técnicas e os conhecimentos dos/as griôs.

Santos (2002) nos alerta que um debate conduzido assim incorre no que denomina de razão metonímica, ou seja, um processo em que os saberes tradicionais de matriz africana - ou qualquer outra forma de conhecimento edificado em racionalidades não europeias - são tomados como simples objetos de estudo da ciência moderna que os descreve, organiza e traduz para uma linguagem científica; e não os reconhecem - os saberes tradicionais - como outras formas de conhecimento cunhadas em outras bases epistemológicas tão válidas quanto as que estabeleceram e constroem as produções científicas, antes toma a parte pelo todo e o estigmatiza como uma saber popular e sem complexidade. Em outras palavras, o/a professor/a deve estar atento a forma como inclui o saber tradicional no debate para não tomar o conhecimento científico como parâmetro.

Ao invés disso, é preciso que o professor esteja preparado para estabelecer um profícuo diálogo entre conhecimentos científicos e conhecimentos tradicionais questionando a pretensa universalidade da ciência europeia, expondo suas limitações. Dessa forma, ao propor esta intervenção pedagógica em que são inclusos os saberes tradicionais de extração de óleo de coco como subsidio para atingir o objetivo de também ensinar conceitos químicos, visamos não reforçar mecanismos de opressão da colonialidade do saber. Para isso, o diálogo estabelecido deve desconstruir possíveis dicotomias que, na verdade, escondem hierarquizações. Antes, ao estabelecer o diálogo do conhecimento científico com o conhecimento tradicional o/a professor/a deve colocar não apenas o que os diferencia, mas, também, atributos que os aproximam e ainda razões pelas quais o científico não deve ser utilizado como padrão para o tradicional e vice-versa (Santos, 2002).

O mencionado diálogo é um desafio para o/a docente. Kundlatsch e Silva (2017), por exemplo, em trabalho que investigou as abordagens multiculturalistas em registros escritos de estudantes na articulação entre conhecimento tradicional indígena e o científico em aulas de química, concluíram que, mesmo que aula tenha se pautado numa abordagem intercultural, a maioria das produções textuais dos/as alunos/as não incorporaram tal perspectiva. As autoras notaram que a maior parte desses registros foram categorizados em um debate multiculturalista assimilacionista - que concebe não ser possível a igualdade de oportunidades a todos/as e, dessa forma, os grupos subalternizados devem assimilar a cultura do grupo dominante identificado em respostas de caráter descritivo - e/ou multiculturalismo diferencialista - que reconhece a pluralidade cultural e a enfatiza, todavia a coloca numa posição estática e essencializada caracterizada por asserções que deram ênfase ao reconhecimento da diferença, porém de forma acrítica. Poucas foram as respostas que associaram o diálogo e a troca culturais, a construção de uma sociedade mais democrática que respeita direitos e reconhece as diferenças. Portanto, o/a professor/a precisa de formação e orientação para atender essa demanda, e é na tentativa de oferecer um caminho possível que a proposta que estamos 
a discutir se coloca.

Feitas essas ponderações, o/a professor/a poderá então discutir, sempre em perspectiva problematizadora, o processo de descodificação da realidade a partir de conceitos científicos e tradicionais. Neste momento, é propício que o/a docente problematize os efeitos da colonialidade junto aos/às alunos/as e discorra sobre o processo de subalternização dos saberes tradicionais como já descrito anteriormente, assim como a importância política, social e econômica de se fazer frente contra aos mecanismos de dominação modernos/coloniais. Os/As alunos/as poderão engajar-se em buscar informações, por exemplo, aos direitos de propriedade intelectual dos saberes tradicionais e investigar a expropriação desses conhecimentos que podem ser usadas pela ciência moderna e patenteados por cientistas e empresas gerando lucros vultuosos que, geralmente, não chegam a essas comunidades (Cunha, 2007; Pantoja, 2014). Não se pode perder de vista que educação problematizadora é educação emancipadora (Francisco Júnior, 2010).

No momento final desta IP proposta, na generalização do conhecimento os/ as alunos/as serão capacitados/as e instigados/as a explicar não apenas os fenômenos apresentados, mas, outrossim, a maior quantidade possível de fenômenos que podem ser explicados pelos mesmos conhecimentos. Neste sentido o/a docente poderá dispor de exemplos variados em que os conceitos de substância, misturas, densidade e forças intermoleculares podem ser aplicados. Sugerimos no plano de IP apresentado o uso de uma atividade prática para avaliar o ensino/aprendizagem para finalizar a intervenção. Todavia, a atividade prática poderá ser desenvolvida em qualquer um dos momentos que descrevemos para desenvolver os objetivos no nível que é possível em cada um desses momentos, seja de problematização inicial, organização ou generalização do conhecimento.

Sugerimos ao/à docente que em perspectiva interdisciplinar desenvolva-se outras discussões relacionadas à extração do óleo de coco como saber tradicional consolidado comunidades quilombolas. Dessa forma, o entendimento de interdisciplinaridade que nos referimos trata-se de um processo de partilha e intercâmbio entre diferentes disciplinas (História, Geografia, Sociologia, Filosofia, Biologia, Matemática etc.), de modo que as fronteiras entre as mesmas sejam invisibilizadas expondo-se, assim, a complexidade dos objetos em estudo. Na esteira de Japiassú (1994), compreendemos que o trabalho interdisciplinar não é a mera abordagem de um objeto sob a ótica desta e daquela disciplina, mas de um processo de interação de discursos e pontos de vistas de disciplinas diversas com o objetivo de solucionar um problema concreto. Em nosso caso, defendemos que o diálogo entre diferentes áreas do conhecimento é fundamental para promover a interculturalidade em sala de aula possibilitando ainda que não apenas conteúdos da química sejam desenvolvidos.

Neste sentido, outros aspectos também podem ser trabalhados, de preferência envolvendo os/as demais membros do corpo docente, a critério do/a professor/a: biológicos - a anatomia e a fisiologia do coqueiro, sua taxonomia; físicos - força 
e energia na etapa de quebra do coco, transferência de calor na etapa de cocção; e matemáticos - quantidades relacionadas à produção do óleo e sua comercialização como meio de subsistência da comunidade entre outros. Dizendo de outro modo, a ação docente, partindo de objetivos de aprendizagem que dizem respeito à química, pode incluir objetivos que abrangem a complexidade do objeto, a saber, a extração de óleo de coco como saber tradicional de matriz africana. Por conseguinte, o/a professor/a pode discutir aspectos da história da comunidade quilombola: a resistência frente ao ethos colonial, a importância da manutenção e valorização dos saberes tradicionais para identidade individual e da comunidade. Necessário é, de forma crítica, estabelecer esse debate em que as marcas violentas da colonização sejam abarcadas para serem problematizadas e superadas.

\section{Algumas conclusões e implicações}

Os conhecimentos tradicionais constituem parte da identidade das comunidades quilombolas e, portanto, não podem ser suprimidos do currículo da educação escolar desses territórios. O currículo hegemônico e homogeneizante eurocêntrico acaba por impedir que tais conhecimentos tenham espaço nas salas de aulas e o desafio de romper essas barreiras é ainda maior quando se trata do ensino de química/ciências. São poucas as pesquisas que se destinam à temática ou que procuram subsidiar professores e professoras para implementarem um currículo que dialogue com os saberes e fazeres tradicionais na perspectiva da interculturalidade.

A partir da metodologia de pesquisa participante, esse artigo partiu dos conhecimentos dos Griôs para o planejamento de uma proposta de intervenção pedagógica em que o conhecimento químico seja ensinado concomitantemente à valorização dos conhecimentos tradicionais. A reflexão a partir das entrevistas realizadas com os/as griôs nos permitiu reconhecer semelhanças e diferenças entre o saber tradicional e o conhecimento científico: enquanto o primeiro é estruturado por unidades perceptuais, o segundo é caracterizado por unidades conceituais; mas ambos buscam dar sentido ao mundo que nos cerca, portanto, não há razões para suprimir esses conteúdos de nossos currículos escolares, especialmente nas escolas quilombolas.

A partir do trabalho investigativo junto aos/à griôs, foi possível sistematizar uma intervenção pedagógica, que apresentamos como uma proposta de ação para professores e professoras, principalmente da modalidade de Educação Escolar Quilombola. Isso para que possam ser, em certa medida, supridos com recursos teóricos e metodológicos para desenvolverem uma ação pedagógica em uma perspectiva de deslocamento epistêmico do currículo estabelecendo um diálogo salutar entre o conhecimento tradicional e a ciência moderna, em especial, a química.

A análise dessa proposta nos mostrou ser possível concretizar um currículo (pré-ativo) conciliador de diferentes formas de conhecimento colocando em jogo discursos que, por um lado, questionam eurocentrismos e, por outro, exaltam a ciência tradicional. É preciso ressaltar que a intenção não é substituir ou avalizar o discurso do 
conhecimento tradicional com o conhecimento científico, o que acaba tomando este último como superior. Defendemos que é possível a coexistência entre essas diferentes formas de conhecimento em que o currículo em ação convoca não apenas o/a professor/a de ciências/química, mas toda a comunidade escolar, seja em âmbito disciplinar ou interdisciplinar, para a efetivação da educação antirracista. Neste sentido, a educação problematizadora pareceu ser um caminho teórico-metodológico coerente para se planejar a intervenção pedagógica analisada, porém mais pesquisas ainda precisam ser feitas, principalmente, a partir do desenvolvimento da referida IP.

No mais, defendemos que este artigo pode contribuir para catalisar o desenvolvimento de mais investigações no ensino de ciências/química, uma vez que apresenta uma alternativa que parece estar na esteira de um debate intercultural que não apenas reconhece a cultura quilombola, mas a inclui como conteúdo curricular nas aulas de química atendendo a demandas caras à população negra desses espaços, quais sejam, a manutenção e valorização de seus saberes tradicionais. Engajadas no giro decolonial, outras produções científicas devem ser incentivadas e realizadas para subsidiar os/ as docentes das escolas quilombolas com estudos e materiais didáticos, assim como, apresentar opções factíveis que garantam e ecoam as vozes griôs no ensino de química.

\section{Referências}

Almeida, M. C. X. (2010). Complexidade, saberes científicos, saberes da tradição. Editora Livraria da Física.

Almeida, E. S., \& Miranda, C. A. S. (2015). História oral, comunidade quilombola e preservação da saúde: Narrativas e rememoração. Anais do X Encontro Regional de História Oral, Salvador.

Bastos, S. N. D. (2013). Etnociências na sala de aula: uma possibilidade para aprendizagem significativa. In Anais do II Congresso nacional de educação e II Seminário Internacional de representações sociais, subjetividade e educação. PUC.

Balieiro, F. F. (2012). Diferenças, sociedade e escola. In Silvério, V. R., Mattioli, E. A. K., \& Madeira, T. F. L. (orgs.). Relações étnico-raciais: um percurso para educadores. EdUFSCar.

Bernardino-Costa, J. (2018). Decolonialidade, Atlântico Negro e intelectuais negros brasileiros: Em busca de um diálogo horizontal. Revista Sociedade e Estado, 33(1), p. 119-137.

Choe, W. (2009). Com a palavra os Mestres Griôs. (Trabalho de conclusão de curso de pós-graduação). Centro de Estudos Latino-Americanos sobre Cultura e Comunicação Escola de Comunicação e Artes, Universidade de São Paulo, São Paulo.

Cunha Jr., H. (2010). Tecnologia africana na formação brasileira. Revista CEAP. 
Cunha, M. C. (2007). Relações e dissensões entre saberes tradicionais e saber científico. In M. C. Cunha, (Ed.), Cultura com aspas e outros ensaios (pp. 301-310). Cosac Naify.

Cunha, M. C. (2010). Saberes tradicionais e saber científico. In E. N. Corrêa, Relatório de participação no seminário: Saberes tradicionais e saber científico. FAFICH/UFMG.

Cunha, M. C. (2012). Questões suscitadas pelo conhecimento tradicional. Revista de Antropologia, 55(1), 439-464.

Delizoicov, D. (1983). Ensino de física e a concepção freiriana de educação. Revista de Ensino de Física, 5(2), p. 85-98.

Demo, P. (2008). Pesquisa Participante: Saber pensar e intervir juntos. 2. ed. Liber.

Fatunmbi, A. F. (2014). Ori: The Ifa Concept of Consciousness. Volume 4 (The Metaphysical Foundations of Ifa). Books2Anywhere.

Fellows, P. (2006). Tecnologia do processamento de alimentos: Princípios e prática. 2a .ed. Artmed.

Fiabani, A. (2015). Tradição africana e os saberes no currículo das escolas quilombolas. África (s) - Revista do Programa de Pós-Graduação em Estudos Africanos, Povos Indígenas e Culturas Negras, 2(3), 72-88.

Francisco Júnior, W. E. (2010). Analogias e situações problematizadoras em aulas de ciências. Pedro \& Joao Editores.

Franzão, J. M. (2017). Comunidades Kalunga e Jardim Cascata: realidades, perspectivas e desafios para o ensino de Química no contexto da educação escolar Quilombola. (Tese de Doutorado em Química). Universidade Federal de Uberlândia, Uberlândia.

Freire, P. (2005). Pedagogia do Oprimido. 43a ed. Paz e Terra.

Gomes, N. L. (2012). Relações Étnico Raciais, Educação e Descolonização de Currículos. Currículo sem Fronteiras, 12(1), p. 98-109.

Haerter, L., Nunes, G. H. L., \& Cunha, D. T. R. (2013). Refletindo acerca da contribuição da cultura quilombola aos currículos da educação básica brasileira, através da presença da história da África e Afro-Brasileira. Identidade! (Online), 18(3), 267-278.

Heritage, J., \& Atkinson, M. (1984). Introduction. In M. Atkinson, \& J. Heritage, Structures of Social Action. Cambridge University Press.

Isenmann, A. F. (2012). Operações unitárias na indústria química, 2a Ed. Edição do Autor. Japiassú, H. (1994). A questão da interdisciplinaridade. http://smeduquedecaxias.rj.gov. br/nead/Biblioteca/Forma\%C3\%A7\%C3\%A3o\%20Continuada/Artigos\%20Diversos/ interdisciplinaridade-japiassu.pdf

Kundlatsch, A., \& Silva, C. S. (2017). Articulando Ciência e Cultura Indígena na escola: análise de uma oficina temática a partir da perspectiva multicultural. In Anais do XI Encontro Nacional de Pesquisa em Educação em Ciências, XI ENPEC. Universidade Federal de Santa Catarina, Florianópolis. 
Le Boterf, G. (1984). Pesquisa Participante: Propostas e Reflexões Metodológicas. In C. R. Brandão, (Org.). Repensando a Pesquisa Participante. Ed. Brasiliense.

Lopes, A. C. (2007). Currículo e epistemologia. Ed. Unijuí.

Marcuschi, L. A. (1986). Análise da Conversação. Ática.

Maciel, L. M. (2012). As quebradeiras de coco babaçu e o mercado: Dilema entre a proteção dos conhecimentos tradicionais e a sujeição jurídica. (Dissertação de Mestrado Direito Ambiental). Universidade do Estado do Amazonas, Manaus.

Menegolla, M., \& Sant'anna, I. M. (2003). Por que planejar? Como planejar? CurrículoÁrea-Aula. 13. ed. Vozes.

Minayo, M. C. (1996). Pesquisa Social: Teoria, método e criatividade. Ed. Vozes.

Moura, G. (2005). O direito à diferença. In M. Kabengele (Ed.), Superando o Racismo na Escola, (pp. 69-82). Brasília, DF: Ministério da Educação, Secretaria de Educação Continuada, Alfabetização e Diversidade.

Nunes, G. H. L. (2014). Educação Escolar Quilombola e Lei 10.639/03: Cartografias territoriais e curriculares. Identidade, 19(1), 89-99.

Oliveira, E. (2009). Epistemologia da Ancestralidade. Entrelugares: Revista de Sociopoética e Abordagens, Afins, 1, p. 1-10.

Oliveira, C., Moura, S. P., \& Sousa, E. R. (2015). TIC’S na educação: A utilização das tecnologias da informação e comunicação na aprendizagem do aluno. Pedagogia em ação, 7(1), 75-95.

Pacheco, L. (2006). Pedagogia griô: A reinvenção da roda da vida. Grãos de Luz e Griô.

Paiva, A. S. (2014). Conhecimentos tradicionais e ensino de biologia: Desenvolvimento colaborativo de uma sequência didática sobre reprodução vegetal. (Dissertação de Mestrado em Educação). Universidade Federal da Bahia, Salvador.

Pantoja, M. C. (2014). "Conhecimentos Tradicionais": Uma Discussão Conceitual. In Anais do VIII Simpósio Linguagens e Identidades da/na Amazônia Sul-Ocidental e do VII Colóquio Internacional "As Amazônias, as Áfricas e as Áfricas na Pan-Amazônia”, Universidade Federal do Acre, Rio Branco, 2014.

Paraná. (2019). Departamento de Direitos Humanos e Cidadania - DEDIHC. Povos e Comunidades tradicionais. Curitiba: Secretaria da Justiça, Trabalho e Direitos Humanos.

Perrelli, M. A. S. (2008). “Conhecimento Tradicional” e Currículo Multicultural: Notas com base em uma experiência com estudantes indígenas Kaiowá/Guarani. Ciência \& Educação, 14(3), 381-96. http://dx.doi.org/10.1590/S1516-73132008000300002

Quijano, A. (2010). Colonialidade do poder e classificação social. In B. Santos, \& M. P. Meneses, (orgs.). Epistemologias do Sul. Margarida Gomes (trad.). Cortez Editora, 2010, p. 84-130. 
Regiani, A. M. (2014). Conhecimento Tradicional e Química: Possíveis aproximações. Editora CRV.

Regiani, A. M., \& Di Deus, E. (2013). A cultura na Química e a Química da cultura: contextualizand o o Ensino de Ciências na amazônia acreana. In IX Congreso Internacional sobre Investigación en Didáctica de las Ciencias, 9. Girona. Atas ... Enseñanza de las Ciencias: Gerona.

Santana, P. M. (2015). Modos de ser criança no quilombo Mato do Tição. (Tese de Doutorado em Educação, Conhecimento e Inclusão Social). Faculdade de Educação da UFMG, Jaboticatubas.

Santos, B. S. (2002). Para uma sociologia das ausências e uma sociologia das emergências. Revista Crítica de Ciências Sociais, 63, 237-280.

Santos, B. S. (2008). Um discurso sobre as ciências. 5. ed. Cortez Editora.

Santos, M. A., Camargo, M. J. R., \& Benite, A. M. C. (2020). Quente e frio: Sobre a Educação Escolar Quilombola e o Ensino de Química. Química Nova na Escola, no prelo.

Secretaria de Políticas de Promoção da Igualdade Racial - SEPPIR / Secretaria de Políticas para Comunidades Tradicionais (2013). I Plano Nacional de Desenvolvimento Sustentável dos Povos e Comunidades Tradicionais de Matriz Africana. http://portal. iphan.gov.br/uploads/ckfinder/arquivos/plano_nacional_desen_sustentavel_povos_ comunidades_trad_matriz_africana.pdf

Silva, C. S. (2013). Do Griô ao Vovô: o contador de histórias tradicional africano e suas representações na literatura infantil. Nau Literária. https://seer.ufrgs.br/NauLiteraria/ article/view/43352/27859

Silva, D. V. C. (2009). A educação das relações étnico-raciais no ensino de Ciências: Diálogos possíveis entre Brasil e Estados Unidos. (Tese de Doutorado em Educação). Universidade Federal de São Carlos, São Carlos.

Silva, T. T. (2005). Documentos de Identidade: Uma introdução às teorias do currículo. Autêntica.

Silva, T. T. (2012). Currículo e identidade social: territórios contestados. In Silva, T. T. Alienígenas em sala de aula: Uma introdução aos estudos culturais em educação. 10a edição, p. 185-201. Vozes. 
Marciano Alves do Santos

(1) https://orcid.org/0000-0001-7385-0266 Universidade Federal de Goiás, Campus Samambaia Instituto de Química Núcleo de Pesquisas em Ensino de Ciências Goiânia, Goiás, Brasil marcianoquilombola@gmail.com

Marysson Jonas Rodrigues Camargo

${ }^{\oplus}$ https://orcid.org/0000-0001-8582-0443

Universidade Federal de Goiás

Campus Samambaia, Instituto de Química Núcleo de Pesquisas em Ensino de Ciências

Goiânia, Goiás, Brasil maryssoncamargo23@hotmail.com

Anna M. Canavarro Benite

${ }^{\circ}$ https://orcid.org/0000-0002-8750-7319

Universidade Federal de Goiás

Campus Samambaia

Instituto de Química Núcleo de Pesquisas em Ensino de Ciências

Goiânia, Goiás, Brasil anitabenite@gmail.com

Submetido em 26 de abril de 2020 Aceito em 03 de agosto de 2020

Publicado em 08 de setembro de 2020 